Vol. 52, no. 1 (2014), pp. 1-24, doi: 10.14421/ajis.2014.521.1-24

\title{
CHANGE AND CONTINUITY IN INDONESIAN ISLAMIST IDEOLOGY AND TERRORIST STRATEGIES ${ }^{1}$
}

\author{
Adam James Fenton \\ Charles Darwin University, Darwin, Australia \\ adamjames.fenton@cdu.edu.au
}

\section{Abstract}

The "Islamisation" of Indonesia has exerted a transformative force on every aspect of Indonesian society. That process continues today. It has created streams of change and continuity in thoughts, ideologies and practices, of enormous complexity. Strict doctrinal interpretation of Koranic text is not a new phenomenon, contrary to what some reports in the mass media might suggest. Its roots stretch back at least as far as the 1800s with the outbreak of violent conflicts between those urging a stricter, scripturalist application of Islam, and those adhering to traditionalist and colonialist ideologies --culminating in the Padri war of West Sumatra of 1821-38. Indicating an ostensible continuity of ideology, modern extremist ideologues, such as Abu Bakar Bashir, urge their followers toward violent conflict and terrorist actions based on an ideology of strict "Middle Eastern" interpretation of fundamental Islamic tenets. This paper argues that the strategies of those carrying out radical and violent ideologies are undergoing change, as are the strategies of the authorities tasked with combating them. Radical groups have displayed a shift away from largescale, attacks on symbolic foreign targets towards low-level violence primarily aimed at law enforcement authorities. Authorities, on the other hand, have shown a greater tendency to shoot dead those suspected of involvement with violent radical groups. This paper will examine the changing strategies of violent radical groups and the continuity, and evolution, of the underlying Islamic

${ }^{1}$ This paper is based on a paper presented at the 6th International Indonesia Forum: Transformation towards the Future; Continuity versus Change in Indonesia (Sunan Kalijaga State Islamic University Yogyakarta, Indonesia, 21-22 August 2013). 
ideology that provides religious justification for their violent acts. The paper will argue that engaging Indonesia's politically active youth in an ideological dialogue on Islamism and democracy provides the best prospect for disengagement from, and breaking the cycle of recruitment for, radical violence and terrorism.

LProses panjang Islamisasi di Indonesia telah menghasilkan kekuatan transformatif di seluruh aspek kehidupan masyarakat Indonesia. Proses ini terus berlangsung hingga sekarang serta menciptakan gelombang perubahan berkesinambungan dalam pemikiran, ideologi, dan praktik-praktik dalam kompleksitas yang rumit. Penafsiran kaku atas ayat-ayat Quran sebenarnya bukanlah sesuatu yang baru, berbeda dengan apa yang selama ini diasumsikan di media. Fenomena seperti ini dapat dirunut kembali pada era 1800 an, khususnya pada konflik bersenjata yang terjadi antara penganjur penerapan tekstual ajaran Islam dengan para penganut ideologi tradisional dan penjajah, yang berpuncak pada Perang Padri di Sumatra Barat tabun 1821-38. Dengan ideologi serupa, para ideolog modern dari kelompok garis keras, seperti Abu Bakar Bashir, mendorong pengikutnya untuk melakukan aksi kekerasan dan teror dengan mendasarkan diripada ideologi ala Timur Tengah dengan penafsiran dasar-dasar Islam secara kaku. Tulisan ini mendalilkan bahwa strategi kelompok yang mengusung ideologi radikal dan kekerasan terus mengalami perubahan seiring perubahan strategi penguasa dalam menghadapi mereka. Strategi kelompok radikal telah berubah dari penyerangan berskala besar terhadap simbol-simbol asing bergeser pada kekerasan berskala kecil terutama pada persoalan penerapan bukum. Pemerintah, di sisi lain, cenderung mengambil tindakan tegas terhadap mereka yang diduga terlibat kekerasan kelompok radikal. Tulisan ini juga melibat perubahan-perubaban dan kesinambungan strategi dari kelompok radikal serta evolusi ideologi Islam yang menjustifikasi aksi-aksi kekerasan. Kesimpulan lainnya adalab babwa keterlibatan kalangan muda dalam kegiatan dialog mengenai Islam dan demokrasi menjadikan mereka terbindar sekaligus memutus rantai rekrutmen gerakan radikal dan terorisme.]

Keywords: terrorism, terrorist strategy, Indonesian ideology, Densus-88, the National Counter Terrorism Agency (BNPT).

\section{A. Introduction}

Here I consider change and continuity in Indonesian Islamist ideology and terrorist strategies in relation to my field of research, 
Indonesian terrorism studies. The discussion will be divided into two parts: ideology and strategies. The hypothesis I explore is that while terrorist strategies are undergoing continual change, there exists an underlying ideology, which continues to sustain and provide a "higher purpose" to violent jihadist activities. It is precisely this ideology --which utilises, misinterprets and manipulates a combination of religious, political and social messages-- which creates a pressing sense of injustice and righteousness in the minds of young, new recruits. Effectively "shortcircuiting" the misuse of this ideology as a tool of recruitment is perhaps the most important task in the prevention of terrorism in Indonesia - a sentiment echoed by People's Consultative Assembly deputy speaker Hajriyanto Thohari when he said "Arrests continue to be made but terrorist suspects continue to emerge. Therefore serious and systematic measures are needed to break the chain (emphasis added)."'

An analysis of media reports and expert commentaries ${ }^{3}$ indicates that terrorist strategies are continually undergoing change. This is in part due to internal influences, however it is also undoubtedly in large part due to the on-going successes of police. The police specialist counterterrorism detachment, Densus 88 , has had extraordinary success in investigating, uncovering, apprehending and neutralising jihadist groups and individuals. Some commentators hasten to add that the police have also had their fair share of luck as terrorists have shown a level of carelessness and ineptitude that has certainly aided police in their task. ${ }^{4}$ In any event, at last count, over the past 10 years, police had arrested over 700 suspects and killed over 60 alleged terrorists in counter terrorism

${ }^{2}$ Markus Junianto Sihalolo and Farouk Arnaz, "Bloody Densus 88 Raids Reveal Disturbing Detail”, Jakarta Globe (11 May 2013), http://www.thejakartaglobe.com/ news/densus-88-searching-for-missing-terrorist-funds/.

${ }^{3}$ Of note are the expert reports compiled by the International Crisis Group in Jakarta. One recent report entitled How Indonesian Extremists Regroup Asia Report $N^{\circ} 22816$ Jul 2012 provides a detailed analysis of the strategic responses of terrorist groups following police raids on a terrorist training camp in Aceh in 2011. The camp was partially funded by radical ideologue Abu Bakar Bashir, who was later convicted of financing terrorism and sentenced to 15 years imprisonment.

${ }^{4}$ Angela Dewan, "Indonesia's Islamic Vigilantes 'Turning to Terrorism"', Jakarta Globe (26 Jan 2012), http:/ / www.thejakartaglobe.com/news/indonesias-islamicvigilantes-turning-to-terrorism/493871\#Scene_1; George Roberts, "Incompetent Terrorists Test Indonesia's Luck”, ABC News (14 Sep 2012), http://www.abc.net.au/ news/2012-09-14/incompetent-terrorists-test-indonesias-luck/4262508. 
operations, ${ }^{5}$ although not without an increasing level of criticism for their tactics as I will discuss further. ${ }^{6}$

Despite these successes, terrorist groups have shown an impressive level of resilience and innovation. The International Crisis Group commented in a July 2012 report that "the country's violent extremists are weak and divided but still active." 7

The second half of 2013 saw a string of shootings and arrests of suspected terrorists, and attacks against police. During the month of August, four police officers were shot and killed allegedly by terrorist groups, and a small bomb exploded at a Buddhist temple in Jakarta, injuring three people, apparently in response to attacks against Rohingya Muslims in Myanmar. ${ }^{8}$

Following the arrest of 17 terrorist suspects in one week in May 2013, the deputy speaker of the People's Consultative Assembly, Hajriyanto Thohari, commented that 'It's really shocking to see the phenomenon that terrorist suspects arrested by officers are getting younger. This means the process of regeneration and recruitment of terrorists is going smoothly and successfully." "9

Another member of parliament from the Indonesian Democratic Party of Struggle (PDI-P), Tjahjo Kumolo, also commented on the emergence of "young, dynamic and energetic terrorists". ${ }^{10}$ These new recruits are younger, internet savvy and enthusiastic, and they have had an impact on terrorist strategies, ranging from financing to recruitment to communications.

\section{B. Continuing Ideology}

How then are these "young, dynamic and energetic" recruits drawn into the potentially fatal world of terrorist related crime? And how can

5 "Buddhist Vihara in Jakarta Bombed, 3 Injured", The Jakarta Post (5 Aug 2013), http://www.thejakartapost.com/news/2013/08/05/buddhist-vihara-jakarta-bombed3-injured.html.

${ }^{6}$ Rabby Pramudatama and Nani Afrida, "After Raids, Focus on Hasmi Group and Terror Links", The Jakarta Post (29 Oct 2012), http://www.thejakartapost.com/ news/2012/10/29/after-raids-focus-hasmi-group-and-terror-links.html.

7 "How Indonesian Extremists Regroup: Asia Report No. 228”, International Crisis Group (16 Jul 2012), http:/ /www.crisisgroup.org/ / media/Files/asia/south-east-asia/ indonesia/228-how-indonesian-extremists-regroup.pdf.

8 "Buddhist vihara".

9 Sihalolo and Arnaz, "Bloody Densus 88".

${ }^{10}$ Ibid. 
we counteract it?

In arguing against the premise that terrorist recruits are drawn to an ideology, reformed radical and founder of the Institute for International Peace Building, Noor Huda Ismail, claims that the decision is an emotional one, not based on ideology:

Most people are drawn to terrorism not because of a set of ideas or lectures; they are driven by a sense of injustice. It is more often an emotional decision than an intellectual one. ${ }^{11}$

However, the ideology recruiters use is precisely one which focuses on the issue of injustice, which specifically aims to evoke an emotional response of anger and righteous indignation. It is a continuing ideology of extremism and fundamentalism that has attracted a small but dangerously influential number of Indonesians for at least the last two hundred years. It is a stream of militant, jihadist, revolutionary thought which emphasises: the urgent rectification of rampant un-Islamic practices, widespread moral decline, the illegitimacy of the national government, Christian and Zionist conspiracies to destroy Islam, injustices suffered by fellow Islamic communities such as Palestine and Myanmar's Rohingya, and the failure of Islam to take its rightful place at the centre of all human experience and interaction. ${ }^{12}$

In the political sphere, the ideology presses for the urgent rectification of the Indonesian Constitution to include a clause obliging all Muslims to be subject to Shariah law. Further, that the Indonesian Republic should be replaced with an Islamic state, the Negara Islam Indonesia and that Shariah (an undefined body of Islamic law) should be implemented, complete with ḅudüd or violent punishments such as stoning and amputation for offenders.

It is an ideology precisely configured to evoke the emotional responses of outrage and aggression - and it is important to note that it misuses and misinterprets passages of sacred texts to develop a quasireligious basis for its conclusions.

While a clear majority of Indonesians are moderate in their views of Islam and its place in the world, some of these arguments clearly strike a

${ }^{11}$ Thomas Roberson, "My Jakarta: Noor Huda Ismail, Founder Institute for International Peace Building”, Jakarta Globe (31 Mar 2012), http:/ / www.thejakartaglobe. com/archive/my-jakarta-noor-huda-ismail-founder-institute-for-international-peacebuilding/508195/.

${ }^{12}$ Greg Fealy and Aldo Borgu, Local Jihad: Radical Islam and Terrorism in Indonesia (Canberra: Australian Strategic Policy Institute, 2005). 
chord with a wide audience; a point supported by empirical data. Sukma, Ma'ruf and Abdullah conducted a survey on the attitudes of Indonesian Muslims to terrorism and concluded:

The analysis in this article is based on the results of a national survey. It is interesting to note that although in general Muslims in Indonesia rejected terrorism as a method of struggle, they have great sympathy for the struggle of their fellow Muslims in other parts of the world. In fact, they are willing to give financial contribution. ${ }^{13}$

The study found that $56 \%$ of respondents supported the application of Shariah in Indonesia, and 27.3\% believed that the Jewish people and Israel were behind the September 11 incident. ${ }^{14}$ This indicates a significant proportion of the population supports the underlying ideology outlined above - whether or not they support the use of terrorism or political violence as a method or response.

Other surveys such as one conducted by the reputable Pew Research Center indicated that $72 \%$ of Indonesians favoured the application of Shariah in Indonesia. ${ }^{15}$ While the wording of questionnaires and methodology may be challenged, ${ }^{16}$ the fact would appear to remain that a significant yet unspecified proportion of Indonesia's Muslim populace would prefer to see the application of Shariah law, at least in relation to the nation's Muslim communities.

Much has been written in recent times about the increasing trend towards radical Islam among Indonesia's mainstream communities. A combination of factors have been pointed to: the reluctance of the President to speak out against Islamism due to political apathy; ${ }^{17}$ growing intolerance, evidenced by attacks against religious minorities such as on

${ }^{13}$ Rizal Sukma, Jamhari Ma'ruf, and Kamarulnizam Abdullah, "The Attitude of Indonesian Muslims Towards Terrorism: An Important Factor in Counter-terrorism?”, Journal of Human Security, vol. 7, no. 1 (2011), pp. 21-36.

${ }^{14}$ Ibid., pp. 30-1.

15 Arientha Primanita and Ethan Harfenist, "Seventy-Two Percent of Indonesian Muslims Favor Shariah Law: Pew Forum", Jakarta Globe (1 May 2013), http://www.thejakartaglobe.com/news / seventy-two-percent-of-indonesians-favor-shariah-law-pew-forum/.

${ }^{16}$ Naila Shofia and Piero Stanig, "Seven Out of Every Ten Muslims in Indonesia Want Shariah — Really?", Jakarta Globe (10 May 2013), http://www.thejakartaglobe. com/opinion/seven-out-of-every-ten-muslims-in-indonesia-want-shariah-really/.

17 "Public Blames Yudhoyono for Rising Religious Intolerance", The Jakarta Post (11 Nov 2013), http://www.thejakartapost.com/news/2013/11/11/public-blamesyudhoyono-rising-religious-intolerance.html. 
the Ahmadiyah sect by a the hardline Islamic Defenders Front (FPI) ${ }^{18}$ the enactment of anti-pornography laws and the gaoling of celebrities ${ }^{19}$ and magazine editors ${ }^{20}$ convicted of contravening those laws and Islamic morality. ${ }^{21}$

Much of Merle Ricklefs' most recent publication on Islam in Java is devoted to measuring social phenomena which indicate a trend towards greater and stricter Islamisation of the Javanese population such as the growing numbers of women who choose to wear the jilbab or Islamic headdress. Abuza speaks of a rise in religiosity and the spread of Salafi Islam. ${ }^{22}$ In discussing the rise of political Islam, Abuza discusses political parties such as the PKS (the Prosperous Justice Party) and draws attention to inconsistencies in their public and internal agendas. As a means of garnering public support "PKS was successful in many ways by downplaying its Islamist message and focussing on an anti-corruption platform popular with secular-minded voters." ${ }^{23}$ For Abuza there is a concealed agenda which is far more wary of Christians and the West, "the private agenda focuses on Islamic purity, internal discpline and sharia". ${ }^{24}$ After discussing the performances of Islamic parties in past elections Abuza concludes that "political Islam appears to be growing in popularity and influence." 25 Similarly, Robert Hefner has referred to the purification of society. ${ }^{26}$ Abuza also refers to statistics which show a rise in pious practices such as wearing the Islamic head covering for women and frequency of praying. ${ }^{27}$

In a similar vein, Noorhaidi Hasan commented:

In tandem with the seemingly rising consciousness of Indonesian Muslims to demonstrate their religious self in the public sphere, Islam

${ }^{18}$ Dewan, "Indonesia’s Islamic Vigilante".

${ }^{19}$ Aubrey Belford, "Indonesian Pop Star Jailed over Sex Tapes", International Herad Tribune (Paris, 31 Jan 2011).

20 "Indonesia vs. Playboy: Press Freedom in Post Reform Indonesia", The Wall Street Journal (New York, 3 Sep 2010).

${ }^{21}$ Merle Calvin Ricklefs, Islamisation and Its Opponents in Java: A Political, Social, Cultural and Religious History, c. 1930 to Present (Singapore: NUS Press, 2012).

${ }^{22}$ Zachary Abuza, Political Islam and Violence in Indonesia (London: Routledge, 2007), p. 92.

${ }^{23}$ Ibid., p. 25.

${ }^{24}$ Ibid.

${ }^{25}$ Ibid., p. 35.

${ }^{26}$ Robert W. Hefner, Civil Islam: Muslims and Democratization in Indonesia (Princeton: Princeton University Press, 2000).

${ }^{27}$ Abuza, Political Islam, p. 93. 
has increasingly moved to the centre and become part of political expressions, legal transactions, economic activities, as well as social and cultural practices. ${ }^{28}$

A further indicator of rising Islamism raised by both Hasan and Abuza is the increase in the number of regional bylaws (Perda, Peraturan Daerah) which attempt to enforce tenets of Shariah at a provincial or sub-provincial level. Hasan also points to increased levels of piety, a rise in Islamic media, the rise of an Islamic pop culture and a Campus-Islam phenomenon which all indicate rising levels of Islamic adherence and belief. ${ }^{29}$ The Campus-Islam phenomenon emphasises purity from vice and "the need to establish an exclusive moral order characterized by a strong commitment to Islamic beliefs, rituals, religious devotion and experiential religiosity" 30

The difficulty of measuring these trends however is clear. In an analysis of the commoditization of religious messages, and the messages of Sufi televangelists, Fealy and Howell, in two separate chapters focussing on trends in Islam concluded that "the pluralist trend appears ascendant in the Indonesian Islamic marketplace," and, "there is a revival of interest in Sufism taking place across the country". 31

Noor Huda Ismail's point that, in the final analysis, strictly religious, ideological or doctrinal justifications may be of less relevance to youth in making the decision to become involved in terrorism may be correct. Angst, alienation and an urge to rebel are arguably universal amongst the world's teenagers. However, two points can be made in response: firstly, the manifold ideology of hate and violence outlined above is an ideology whether it has a partial religious basis or not, and secondly, the extent to which ideology or religious texts and justifications play a role in any individual's choices will vary depending on each individual. Indeed a statistical analysis of the motivations of young Indonesians who undertake terrorist violence would form the basis of useful quantitative research, although it appears that no comprehensive data has been collected in that area. In any event, the appeal for and uptake of this

${ }^{28}$ Noorhaidi Hasan, "The Making of Public Islam: Piety, Agency, and Commodification on the Landscape of the Indonesian Public Sphere", Contemporary Islam, vol. 3, no. 3 (2009), p. 230.

${ }^{29}$ Ibid., pp. 229-50.

${ }^{30}$ Ibid., p. 233.

${ }^{31}$ Greg Fealy and Sally White (eds.), Expressing Islam: Religious Life and Politics in Indonesia (Singapore: Institute of Southeast Asian Studies, 2008). 
ideology of hate by Indonesia's Muslim youth, is an area which requires careful attention and further research if governments and lawmakers are serious about "breaking the chain".

\section{Historical Roots of Violent Ideology}

While recognising that the vast majority of Indonesians reject violence and are relatively moderate in their views about the place of Islam in their lives and their communities, it must be recognised that an unspecified minority does advocate a violent approach to the strict implementation of Islam in Indonesia. Where, then, did this uncompromising, intolerant and violent ideology stem from? Indonesian people are, after all, known to be some of the most friendly, welcoming people in the world. To answer that question we must look at history. Those who have studied even the most basic history of the Indonesian archipelago will know that the two great world religions to arrive in Indonesia prior to European contact were Hindu-Buddhism and Islam. Both came as the result of maritime technology and trade via India. ${ }^{32}$

While most people in the West automatically identify Islam with Arabs, the reality is that Arabs only make up around 15\% of the world's Muslims. ${ }^{33}$ Indonesia, Pakistan, India and Bangladesh, situated in South and South-east Asia, are the world's four most populous Muslim societies and together make up over $50 \%$ of the world's Muslims. ${ }^{34}$

In discussing the arrival of Islam in Indonesia the role of the Sufi mystics is a key element. As this passage from historian Dong Sull Choi points out:

Unlike Islam in the Middle East and India, Indonesia was not conquered by force. The Sufis came not only as teachers but as traders and politicians...Sufism is the science of the direct knowledge of God; its doctrines and methods derive from the Koran and Islamic revelation. Sufism freely makes use of paradigms and concepts derived from Greek and even Hindu sources. The Sufis communicated their religious ideas in a form compatible with beliefs already held in Indonesia. For instance, pantheistic doctrines were easily understood because of Hindu teachings extant in the archipelago. The resemblance between the Sufi outlook and

${ }^{32}$ For a complete history of the arrival of Islam in Indonesia, see Merle Calvin Ricklefs, A History of Modern Indonesia, ca. 1300 to the Present (Bloomington: Indiana University Press, 1981).

${ }^{33}$ Dong Sull Choi, "The Process of Islamization and its Impact on Indonesia”, Comparative Civilizations Review, no. 34 (1996), pp. 11-26.

${ }^{34}$ Ibid. 
Hinduism was great. The Sufis stressed religious retreats and minimized the importance of mosque worship...and, of course, centered their belief on the individual mystical experience of God. ${ }^{35}$

In its earliest guises, therefore, Islam in Indonesia was not presented as a strict alternative to the existing Hindu-Buddhist beliefs and pantheon of gods. It was hugely adaptable, and local practices and customs such as the wayang were used by early Muslim missionaries to win over the local populace. Indonesian Islam is, as Choi puts it, "rather different from the austere form found in the Middle East." 36

So when and how did this continuing tension arise between the accommodating, syncretic, mystical form of Sufi Islam and the more austere Wahhabist form? Scholars appear to agree that it dates back to around the 1780s with the arrival back in West Sumatra of Muslim pilgrims who had completed the obligatory Haj pilgrimage to the sacred sites of Islam.

Writing about this period of Indonesian history, Greg Fealy commented that:

From the 1780s, people returning from the pilgrimage and study in the Middle East set about "reforming" local Islamic practices and applying Islamic law more strictly in the region. They opposed gambling, the use of intoxicants, and "un-Islamic" entertainment such as cockfighting. Their uncompromising puritanism sparked fierce resistance from the local religious and political elite and from the Dutch, and eventually led to the outbreak of the Padri Wars during the early decades of the nineteenth century. ${ }^{37}$

The tension between the Padri and the Sufi Tarekat orders, as well as the Dutch colonial authorities who were drawn into the conflict, developed into an all-out war which raged from 1821 to 1838. As George Fowler explains:

Although the Padri were ultimately crushed by the Dutch forces and their main leaders either killed or exiled, a more orthodox form of Islam had succeeded in establishing itself by expanding religious schools and strengthening the position of religious teachers in the nagari. ${ }^{38}$

From the mid-1800s, therefore, a strict Wahhabist interpretation of

${ }^{35}$ Ibid., p. 17.

${ }^{36}$ Ibid., p. 14.

${ }^{37}$ Fealy and Borgu, Local Jihad, p. 17.

${ }^{38}$ Marah Rusli, Sitti Nurbaya: A Love Unrealized, English edition (Jakarta: Lontar Foundation, 2009), p. xv. 
Islam had begun to take hold in some parts of the Indonesian archipelago. Contemporaneous and subsequent events would reinforce this violent mentality in the minds of some of its adherents. These included the Java war of 1825 to 1830 during which Javanese Prince Diponegoro used Islam as a banner around which to rally and unify his troops against the infidel, foreign oppressors, the Dutch.

During the 20th century there were a string of political and military defeats which contributed to a sense of outrage, resentment and grievance among some Islamic groups. Among them was the failure of Islam to be specially recognised in the Constitution. The so-called "Jakarta Charter" issue centred around "nine little words" omitted from the Constitution at the last minute which would have obliged all Indonesian Muslims to follow the precepts of Islamic law. ${ }^{39}$ Then there was the Darul Islam (DI) uprising of the 1940s, 50s and 60s - led by the charismatic Javanese spiritualist leader Kartosoewirjo. While Kartosoewirjo was captured and executed in 1962, an event which effectively put an end to the uprising, it is important to note that out of the ashes of DI grew Jemaah Islamiyah (JI) and all of its subsequent offshoot organisations. JI, which still exists and operates in Indonesia, is a violent organisation formerly led by $\mathrm{Abu}$ Bakar Bashir and responsible for the heinous Bali bombings of 2002.

During the Soeharto New Order era, there were further government actions which provoked a sense of righteous indignation and grievance from hard-line Islamist groups. The Asas Tunggal legislation of 1983 required all social organisations to proclaim Pancasila as their ideological basis. There were also instances of state brutality against Islamic groups such as the 1984 Tanjung Priok shootings and Lampung in 1989. ${ }^{40}$

There were other key international events in the 1970s and 80s which led to the rise of extremist ideology and terrorist groups willing to use violence to achieve their goals. The Iranian revolution was a galvanizing moment which showed that an Islamic revolutionary movement could throw off a western backed regime and establish an Islamic state. Also, Indonesian Mujahidin went to Afghanistan to train and fight and brought back bomb-making and military skills. At the same time, increasing numbers of Indonesians received their education in Middle Eastern countries such as Egypt, Saudi Arabia and Palestine. All of these factors led to a growing ideology among fundamentalist

${ }^{39}$ Timothy Lindsey, Indonesia: Law and Society, 2nd edition (New South Wales: The Federation Press, 2008).

${ }^{40}$ Ibid. 
groups based on overthrowing the "illegitimate" state government and establishing an Islamic state through violent revolution. ${ }^{41}$

\section{Changing Strategies}

Returning to the theme of change and continuity; having discussed the continuing underlying ideology of terrorist groups we turn now to discuss their changing and evolving strategies. How have terrorist strategies in Indonesia evolved in recent years and what useful lessons and predictions can we draw from those observations?

It is worth noting that the last major terrorist bombing was the Marriott/Ritz Carlton attack of 2009 in which there were seven fatalities and 50 injured. Also a key event in the same year, a plot to assassinate President Susilo Bambang Yudhoyono (SBY) and launch a massive Mumbai-style attack against state officials, hotels and tourists, planned for Indonesian Independence day the 17th August, was uncovered and foiled by police. ${ }^{42}$ This planned attack, although unrealised, marked a turning point of sorts. No longer were terrorists merely targeting foreigners in foreign hotels. This event, with its undeniably personal element aimed directly at the Indonesian President and the most senior members of the state apparatus saw terrorism treated as a serious state security issue for the first time, rather than just an extraordinary crime. It led to the fasttracked formation of the National Counter Terrorism Agency (BNPT) and to a major tactical shift in counter-terrorism tactics. Given subsequent events it is reasonable to ask whether, following the uncovering of this plot, Densus 88 were given orders to shoot to kill.

Whereas all of those responsible for the Bali bombings of 2002 were apprehended alive, and went on to stand trial, since around $2009 / 2010$ the instances of fatal police shootings of terrorist suspects have increased dramatically. On the other side of the coin, since around

${ }^{41}$ Fealy and Borgu, Local Jihad. It should be noted that while this paper focuses on Islamist or Jihadist terrorism in Indonesia - this is not the only form or motivation for terrorism in the country. There are other groups which are willing to use shocking violence against civilians to bring attention to their causes. One notable example is ethno-separatist groups in Papua, who have engaged violent strategies against police and civilians, and who could arguably be labeled as terrorist; Sidney Jones, "Papuan 'Sparatists' vs Jihadi ‘Terrorists': Indonesian Policy Dilemmas”, International Crisis Group (22 Jan 2013), http://www.crisisgroup.org/en/publication-type/speeches/2013/jonespapuan-separatists.aspx, accessed 19 Sep 2013.

42 "Indonesia 'Uncovers Plot to Kill President”', BBC News (2010), http:/ / news. bbc.co.uk/2/hi/asia-pacific/8682822.stm, accessed 9 Dec 2013. 
2010, almost all fatalities from "terrorist" attacks have been police. "Since 2009 , all but one of those killed by jihadists or in terrorist attacks in Indonesia have been police: ten in 2010, three in 2011 and eight in 2012." ${ }^{\prime 43}$

It could be said that, in effect, a war is raging between two discrete factions: Jihadist groups on the one hand and the Indonesian Police (Polri) on the other. It may be argued that this change indicates an ideological shift on the part of terrorist groups from targeting the "far enemy" to the "near enemy", although it appears just as likely that this war is fuelled to a large extent by simple revenge.

That may be true, but there are also practical reasons for terrorists to target police - and there is undoubtedly much debate and discussion within terrorist groups about which targets are most appropriate and strategically beneficial. Large bombings of public places indiscriminately kill too many Muslims and can lead to a backlash from the very people the terrorist groups are trying to recruit to their cause. Killing police on the other hand has many practical benefits, it is a source of weapons, and it gives fellow mujabidin something to do, especially after they have received their basic training. A simple low level attack on a police post may also be a kind of initiation rite for a newly trained fighter. It must be asked though, whether the real aim of the attacks is to create fear? If not we may need to rethink labelling and prosecuting these attacks as terrorism.

As Jones points out:

It used to be that jihadis saw the creation of fear as a very specific objective. One man involved in the 2004 Australian embassy bombing, when asked what his aim was, said, "We wanted to make Western nations tremble." The aim now isn't that cosmic; it's much more instrumental. It's about getting weapons, taking revenge, and giving militants something to do, particularly after they've undergone training. While the attacks are sometimes couched -usually after the fact-- in terms of moving against thaghut (anti-Islamic oppressors supported by the West), that kind of rationalisation is less frequent these days. The main aim of killing police is certainly not to create fear. ${ }^{44}$

Therefore, the first major change in terrorist strategies that we can point to over the past few years, is that terrorist groups have gone from large-scale bombing operations of symbolic foreign targets (Bali nightclubs, Embassies, foreign-owned hotels) to low-cost, low-level attacks against Indonesian police officers. On the other side, police

${ }^{43}$ Jones, "Papuan Separatists".

${ }^{44}$ Ibid., p. 2. 
have also shown a marked increase in the numbers of fatal shootings of terrorist suspects.

Another event which had a major impact on the daily operations and changing strategies of terrorist groups in Indonesia was the police raid of a terrorist training camp in Aceh in 2010. This event created repercussions and effects on the methods and inter-relations of terrorist groups which are still being felt today. The raid itself led to over 200 arrests and yielded large amounts of intelligence. However, it also showed that the commitment to large-scale organised jihad was, at that time, still high. Following its discovery and disbanding by police, it inspired a new wave of activity fuelled by revenge as groups were forced to disperse and form new alliances in other parts of the archipelago such as Poso, Bima, Solo and parts of East Kalimantan. ${ }^{45}$

Police raids such as this force these groups to reassess their regrouping strategies as they merge, assist each other and blur the lines between their groups. There are many different terrorist groups currently operating in Indonesia: Jemaah Islamiyah, Jemaah Anshorut Tauhid, Ring Banten, DI Akram, Mujahidin KOMPAK, Mujahidin Indonesian Timor to name just a few, but they all share a similar underlying ideology and they will group together and assist one another when they are "on the run". 46

What conclusions can then be drawn from an examination of the evolving strategies of Indonesian terrorist groups? They appear to be increasingly unsophisticated, fly-by-night and underfunded. We have noted the trend away from large sophisticated bombings, which require significant levels of planning and funding, towards relatively cheap and simple police shootings. There have also been other low-tech plots such as a failed plot to poison police with ricin, and instances of stabbings and small bombs. ${ }^{47}$

Terrorist financing is another important area where the strategies of

45 "Indonesian Jihadism: Small Groups, Big Plans", International Crisis Group (2011), http://www.crisisgroup.org/en/regions/asia/south-east-asia/indonesia/204indonesian-jihadism-small-groups-big-plans.aspx.

${ }^{46}$ Ibid.

47 Zubaidah Nazeer, "Fears Over New Sulawesi Terror Group", Jakarta Globe (13 Feb 2013), http://www.thejakartaglobe.com/archive/fears-over-new-sulawesiterror-group/571473/\#Scene_1; "Police Arrest Suspect in Murder of Brimob Officer", The Jakarta Post (6 Nov 2013), http://www.thejakartapost.com/news/2013/11/06/ police-arrest-suspect-murder-brimob-officer.html; Rahmat, "Man Hurls Bomb at South Sulawesi Governor", Jakarta Globe (12 Nov 2012), http://www.thejakartaglobe.com/ archive/man-hurls-bomb-at-south-sulawesi-governor/555657/\#Scene_1. 
both the terrorist groups and law enforcement agencies are undergoing change. It is worth noting that the first Bali bombing was directly funded by an external international source; Al-Qaeda. However, since then, international counter-terrorism financing laws have become much more sophisticated and international sources of funds have long since dried up. Now, local terrorist groups are forced to find methods to finance themselves, and this usually means by fai or by committing crimes where the proceeds are used to fund terrorism. There have been several cases of robberies of banks and jewellery stores - one terrorist group was even forced to steal motorcycles and resell them on the black market. ${ }^{48}$ A more lucrative source of funds has been internet fraud; the Head of Indonesia's counter-terrorism agency revealed in 2012 that terrorists had been successful in hacking multi-level marketing sites and stealing around Rp7-8 billion (approximately AU $\$ 700,000) .{ }^{49}$ Given that the Bali bombing was funded with only around $\$ 40,000$, the potential for the destructive use of such funds is enormous.

One method of financing which Indonesian terrorist groups have thankfully not yet resorted to, is kidnapping for ransom. This practice has been successfully implemented by terrorists in other parts of the world, particularly sub-Saharan Africa. For example, "Al-Qaeda in the Islamic Maghreb, active in West Africa, has made hundreds of thousands of euros kidnapping foreigners and demanding huge ransoms for their safe return." 50

In response to pressures from the international community, particularly the Financial Action Task Force (FATF), in March 2013 Indonesia brought its counter-terrorism financing legislation into line with its commitments under international law, with the enactment of Law No.9 2013 on the Prevention and Eradication of the Financing of Terrorism (Undang-undang Pencegahan dan Pemberantasan Tindak Pidana Pendanaan Terorisme 2013). While the laws provide a legislative regime for the monitoring of suspicious transactions, and oblige financial services providers to apply "Know Your Customer" procedures, with significant penalties for non-compliance, the laws are not yet being applied to their

48 "Indonesian Jihadism".

${ }^{49}$ Sandro Gatra, "Memutus Rantai Terorisme dengan Senjata Undang-Undang", Indonesia Media (13 Sep 2012), http://www.indonesiamedia.com/2012/09/13/ memutus-rantai-terorisme-dengan-senjata-undang-undang/.

${ }^{50}$ Richard Barrett, "Preventing the Financing of Terrorism", Case Western Reserve Journal of International Law, vol. 44, no. 3 (2012), p. 725. 
full potential. Consequently, the FATF continues to include Indonesia on its list of "high risk or non-cooperative jurisdictions." 51 It remains for overseeing financial bodies such as the PPATK (Indonesian Financial Transactions and Reports Centre), in cooperation with police, to ensure the effective application of the laws so that financing of terrorist groups is effectively cut off. ${ }^{52}$

Finally, how have recruitment strategies evolved and changed over recent years? A number of points may be made here. As increasing numbers of terrorists are convicted and sent to prison, prisons and prison visits have played an increasingly important role in recruiting and reinforcing bonds between radical individuals. Other methods for recruiting vulnerable candidates to the cause of violent jihad include: pengajian, or Islamic study groups, at mosques or university campuses which have been targeted as recruiting grounds; internet chat forums and social media sites such as Facebook, ${ }^{53}$ and the targeting of unemployed men living near mosques. ${ }^{54}$ Younger siblings of slain or imprisoned extremists have proven to be good targets for radical recruiting and show the importance of family ties in building and maintaining networks of terrorist connections. Arranged marriages have also been instrumental in reinforcing bonds. And finally taklim or fiery sermons filled with hate speech and incitement to violence, by radical clerics can serve as informal meeting points for those with similar radical views. ${ }^{55}$ Comprehensive government strategies for monitoring and countering these forms of

${ }^{51}$ Financial Action Task Force Annual Report 2011-2012 (2012), http:/ /www.fatfgafi.org/media/fatf/documents/brochuresannualreports/FATF annual report 2011 2012 website.pdf; "The Financial Action Task Force Public Statement", The Financial Action Task Force (21 Jun 2013), http://www.fatf-gafi.org/countries/d-i/indonesia/ documents/public-statement-june-2013.html.

${ }^{52}$ For a full discussion of the Indonesian counter-terrorism financing legislation, see: Adam Fenton, “Forbidden Funds - Indonesia's New Counter-terrorism Financing Legislation", presented at the The 4th CILS International Law Conference on Transnational Organized Crime Jakarta: Center for International Law Studies, Faculty of Law, Universitas Indonesia and Faculty of Law, Universitas Syiah Kuala, Banda Aceh, 28 Oct 2013), in press.

53 Farouk Arnaz, Indonesian Terrorists Getting More Web-Savvy (31 May 2013), http://www.thejakartaglobe.com/news/jakarta/ indonesian-terrorists-getting-more-web-savvy/.

${ }^{54} \mathrm{~J}$. Templin, "Keeping Radical Islamists from Recruiting on Indonesia's Campuses”, Time (2013), http://www.time.com/time/video/pla yer/0,32068,1118418176001_2089992,00.html.

55 "Indonesian Jihadism". 
recruitment are needed to effectively neutralise and short-circuit the cycle of recruitment and violence. New laws to silence the hate speech of radical clerics have also been proposed, although they raise inevitable concerns about the right to freedom of speech. One commentator has pointed to a legal loophole which allows terrorists to spread hate speech online without fear of prosecution. ${ }^{56}$

A further concern is recidivism. There have been many instances of prisoners, who, upon their release from prison, either re-established contact with old networks or were introduced to terrorist networks while in prison. There have also been several examples of ordinary prisoners being recruited and radicalised in prison that then go on to commit Islamist violence upon their release. ${ }^{57}$

In Indonesia, experts say, some radicals finish their sentences with an even greater commitment to deadly jihad. Of 120 arrested and 25 killed in raids since February 2010, some 26 had previously been in prison for terrorist acts, according to the International Crisis Group, which researches deadly conflict. ${ }^{58}$

The effective monitoring of prison populations, the separation of radicalising prisoners from the general prison population, and the post-release monitoring of prisoners are all areas in which authorities could make gainful improvements in their standard operating procedures. While some attempts at prison-based deradicalisation programs have been made, there appears to be no standardised nation-wide program. Rather, ad hoc attempts depend on the individual efforts of prison authorities at each institution. ${ }^{59}$

With hundreds of convicted terrorists due for release from prison over the next few years, preventing terrorists from reoffending is perhaps one of the greatest challenges. Non-state programs may offer useful

${ }^{56}$ Arnaz, Indonesian Terrorists.

${ }^{57}$ Ninik Karmini, "Teaching Jihad in Indonesian Prisons", Jakarta Globe (30 Jun 2011), http:/ / paywall.thejakartaglobe.com/archive/teaching-jihad-in-indonesianprisons/?doing_wp_cron=1386649956.1412270069122314453125>; Margot O’Neill, "Indonesian Jails Used as Terrorist Incubators", ABC News (18 May 2011), http:/ / www. abc.net.au/news/2011-05-18/indonesian-jails-used-as-terrorist-incubators/2718998; Carl Ungerer, Jihadists in Jail: Radicalisation and the Indonesian Prison Experience, Annual Report (Canberra: ASPI-RSIS, 2011), https://www.aspi.org.au/publications/specialreport-issue-40-jihadists-in-jail-radicalisation-and-the-indonesian-prison-experience/ SR40_jihadists_in_jail.pdf.

${ }^{58}$ Karmini, "Teaching Jihad".

${ }^{59}$ Ungerer, Jihadists in Jail. 
models for disengagement and deradicalisation, such as that run by Noor Huda Ismail - founder of the Institute for International Peace Building. ${ }^{60}$ As reformed radical Ismail explains, reintegrating former terrorists can be achieved by providing employment opportunities and a cognitive opening:

We encourage critical thinking. Some of the former criminals work in a restaurant with an Australian chef. In a cafe, you cannot choose your customers; every visitor must be served equally nicely. It helps to show them that all people are equal. It gives them what I call a cognitive opening, which provides them different perspectives on things. These interactions allow them to establish a level of trust. ${ }^{61}$

Strategies of both terrorist groups and law enforcement agencies are in a state of constant change - a fact which presents challenges for terrorism studies in any country. Strategies for the choice of targets, financing, recruiting, and networking have all shown significant changes over recent years. Obviously the effect of the internet on terrorist communications, financing and operations has been significant. Enforcement strategies must therefore be developed which take account of and tackle these changing modes of operation.

\section{E. Concluding Remark}

What predictions can be made about future events? What have terrorist groups learned and how will that affect their behaviour in future? With major police raids such as the one on the Aceh training camp, terrorist groups now realise the extent to which they have been infiltrated and surveilled by police and that they need to be much more careful in vetting new members before they trust them. They will become much more secretive and careful about who they reveal their plans to. ${ }^{62}$

At the same time, police will probably come under more pressure to respect human rights, legal processes, the presumption of innocence and non-lethal alternatives to fatally shooting suspects. These factors, combined with the impending release of hundreds of convicted terrorists in the coming years, present a huge challenge for law enforcement authorities who have struggled to maintain community support, and to safeguard their own safety, let alone the safety of the wider community. When Indonesia's new Chief of Police Sutarman took over from Timor
${ }^{60}$ Roberson, "My Jakarta".
${ }^{61}$ Ibid., p. 1.
62 "Indonesian Jihadism". 
Pradopo there were calls for him to ensure the safety of the community by arresting those responsible for attacks on police. ${ }^{63}$

In conclusion, what lessons can the Indonesian government and law enforcers learn from the preceding discussion? The following points may be offered:

- Greater attention is needed in identifying and countering issues of recruitment/ideology through a dialogue which engages Muslim scholars and Muslim youth.

- The ideas and recommendations of young Indonesian scholars of social sciences and law who are conducting research in this area should be sought out and implemented.

- Law Reform; the use of hate speech as an ideological tool of recruitment must be tackled in a way which is consistent with community expectations on principles of free speech.

- Effective application of counter-terrorism financing laws by the PPATK and police is needed to cut-off terrorist financing and bring Indonesia into line with its international obligations as set out by the FATF.

- Implementation of a comprehensive nation-wide prison deradicalisation/disengagement program.

- Greater monitoring of terrorist prisoners during their prison sentence and post-release to ensure that they do not re-establish contacts with terrorist networks upon release.

- Post release programs to reintegrate prisoners back into society should be encouraged, e.g. program run by Noor Huda Ismail employing released terrorists in a local restaurant.

- Review and reform police procedures where necessary, including:

- Non-lethal alternatives to shooting

- Use of torture

- Lack of oversight or review

- Tighter airport security; terrorists have been able to travel freely using false documents.

A culture of police violence against suspects leads to further violence in retaliation. Shakespeare expressed this concept most succinctly

${ }^{63}$ Sandro Gatra, "Pesan untuk Sutarman: Jangan Lupakan Penembakan Polisi!”, Kompas.com (Jakarta, 9 Oct 2013), http://nasional.kompas.com/ $\mathrm{read} / 2013 / 10 / 09 / 0952184 /$ Pesan.untuk.Sutarman.Jangan.Lupakan.Penembakan. Polisi. 
and powerfully in the phrase "blood begets blood" in Macbeth (Act III Scene IV). While a certain level of violence is sometimes necessary in police operations to apprehend violent and armed suspects, police ought to be cautious in using unnecessary and excessive force.

Most importantly perhaps, returning to the original question of how to "short circuit" continuing recruitment through the abuse of a continuing ideology, it is important to grapple with that ideology. Young Indonesians need to be educated on the principles of democracy and the notion that in a democracy individuals and groups have the right to agitate for political and social change. To hold the view that Indonesia ought to become an Islamic state and strictly apply the tenets of Shariah law is a valid political goal. In a true democracy there should be no stigma attached to those who hold this view, just as the establishment of a communist utopia is a valid political stance or ideal. It is the methods which individuals and groups use to express and bring about those political and social changes which are in question. The non-violent expression of political views is essential in a true and fully-functioning democracy. However, the use of shocking violence against civilians can never be condoned or accepted under any circumstances. Indonesia's politically active youth, and for that matter some senior political actors, must be made to see that non-violent political dissent is the only acceptable means of political expression. In illustrating the point, it may be helpful to emphasise to Indonesia's future political leaders that the massive political changes made possible during the Arab Spring were through peaceful protest rather than terrorist action, which is ultimately self destructive. 


\section{BIBLIOGRAPHY}

Abuza, Zachary, Political Islam and V iolence in Indonesia, London: Routledge, 2007.

Arnaz, Farouk, Indonesian Terrorists Getting More Web-Savry, 31 May 2013, http:/ / www.thejakartaglobe.com/news/jakarta/indonesianterrorists-getting-more-web-savvy/.

Barrett, Richard, "Preventing the Financing of Terrorism", Case Western Reserve Journal of International Law, vol. 44, no. 3, 2012, pp. 719-36.

Belford, Aubrey, "Indonesian Pop Star Jailed over Sex Tapes", International Herad Tribune, Paris, 31 Jan 2011.

"Buddhist Vihara in Jakarta Bombed, 3 Injured", The Jakarta Post, 5 Aug 2013, http://www.thejakartapost.com/news/2013/08/05/ buddhist-vihara-jakarta-bombed-3-injured.html.

Choi, Dong Sull, "The Process of Islamization and its Impact on Indonesia”, Comparative Civilizations Review, no. 34, 1996, pp. 11-26.

Dewan, Angela, "Indonesia's Islamic Vigilantes 'Turning to Terrorism", Jakarta Globe, 26 Jan 2012, http://www.thejakartaglobe. $\mathrm{com} /$ news/indonesias-islamic-vigilantes-turning-toterrorism/493871\#Scene_1.

Fealy, Greg and Aldo Borgu, Local Jihad: Radical Islam and Terrorism in Indonesia, Canberra: Australian Strategic Policy Institute, 2005.

Fealy, Greg and Sally White (eds.), Expressing Islam: Religious Life and Politics in Indonesia, Singapore: Institute of Southeast Asian Studies, 2008.

Fenton, Adam, "Forbidden Funds - Indonesia's New Counter-terrorism Financing Legislation", presented at the The 4th CILS International Law Conference on Transnational Organized Crime, Jakarta: Center for International Law Studies, Faculty of Law, Universitas Indonesia and Faculty of Law, Universitas Syiah Kuala, Banda Aceh, 28 Oct 2013.

Financial Action Task Force Annual Report 2011-2012, 2012, http:/ /www. fatf-gafi.org/media/fatf/documents/brochuresannualreports/ FATF annual report 20112012 website.pdf.

Gatra, Sandro, "Memutus Rantai Terorisme dengan Senjata UndangUndang", Indonesia Media, 13 Sep 2012, http:/ / www.indonesiamedia. com/2012/09/13/memutus-rantai-terorisme-dengan-senjata- 
Adam James Fenton

undang-undang/.

----, "Pesan untuk Sutarman: Jangan Lupakan Penembakan Polisi!", Kompas.com, Jakarta, 9 Oct 2013, http://nasional.kompas.com/ $\mathrm{read} / 2013 / 10 / 09 / 0952184 /$ Pesan.untuk.Sutarman.Jangan. Lupakan.Penembakan.Polisi.

Hasan, Noorhaidi, "The Making of Public Islam: Piety, Agency, and Commodification on the Landscape of the Indonesian Public Sphere", Contemporary Islam, vol. 3, no. 3, 2009, pp. 229-50 [doi: 10.1007/s11562-009-0096-9].

Hefner, Robert W., Civil Islam: Muslims and Democratization in Indonesia, Princeton: Princeton University Press, 2000.

"How Indonesian Extremists Regroup: Asia Report No. 228”, International Crisis Group, 16 Jul 2012, http://www.crisisgroup.org/ /media/ Files/asia/south-east-asia/indonesia/228-how-indonesianextremists-regroup.pdf.

"Indonesia 'Uncovers Plot to Kill President", BBC News, 2010, http:/ / news.bbc.co.uk/2/hi/asia-pacific/8682822.stm, accessed 9 Dec 2013.

"Indonesia vs. Playboy: Press Freedom in Post Reform Indonesia", The Wall Street Journal, New York, 3 Sep 2010.

"Indonesian Jihadism: Small Groups, Big Plans", International Crisis Group, 2011, http:/ /www.crisisgroup.org/en/regions/asia/south-east-asia/ indonesia/204-indonesian-jihadism-small-groups-big-plans.aspx.

Jones, Sidney, 'Papuan 'separatists' vs Jihadi 'terrorists': Indonesian Policy Dilemmas", International Crisis Group, 22 Jan 2013, http:/ / www.crisisgroup.org/en/publication-type/speeches/2013/jonespapuan-separatists.aspx, accessed 19 Sep 2013.

Karmini, Ninik, "Teaching Jihad in Indonesian Prisons", Jakarta Globe, 30 Jun 2011, http:/ / paywall.thejakartaglobe.com/archive/teachingjihad-in-indonesian-prisons/?doing_wp_cron=1386649956.14122 70069122314453125>.

Lindsey, Timothy, Indonesia: Law and Society, 2nd edition, New South Wales: The Federation Press, 2008.

Nazeer, Zubaidah, "Fears Over New Sulawesi Terror Group", Jakarta Globe, 13 Feb 2013, http:/ / www.thejakartaglobe.com/archive/fearsover-new-sulawesi-terror-group/571473/\#Scene_1. 
O’Neill, Margot, "Indonesian Jails Used as Terrorist Incubators", $A B C$ News, 18 May 2011, http://www.abc.net.au/news/2011-05-18/ indonesian-jails-used-as-terrorist-incubators/2718998.

"Police Arrest Suspect in Murder of Brimob Officer", The Jakarta Post, 6 Nov 2013, http://www.thejakartapost.com/news/2013/11/06/ police-arrest-suspect-murder-brimob-officer.html.

Pramudatama, Rabby and Nani Afrida, "After Raids, Focus on Hasmi Group and Terror Links", The Jakarta Post, 29 Oct 2012, http:/ / www.thejakartapost.com/news/2012/10/29/after-raids-focushasmi-group-and-terror-links.html.

Primanita, Arientha and Ethan Harfenist, "Seventy-Two Percent of Indonesian Muslims Favor Shariah Law: Pew Forum", Jakarta Globe, 1 May 2013, http:/ / www.thejakartaglobe.com/news/seventy-twopercent-of-indonesians-favor-shariah-law-pew-forum/.

"Public Blames Yudhoyono for Rising Religious Intolerance", The Jakarta Post, 11 Nov 2013, http://www.thejakartapost.com/ news/2013/11/11/public-blames-yudhoyono-rising-religiousintolerance.html.

Rahmat, "Man Hurls Bomb at South Sulawesi Governor", Jakarta Globe, 12 Nov 2012, http:/ /www.thejakartaglobe.com/archive/man-hurlsbomb-at-south-sulawesi-governor/555657/\#Scene_1.

Ricklefs, Merle Calvin, Islamisation and Its Opponents in Java: A Political, Social, Cultural and Religious History, c. 1930 to Present, Singapore: NUS Press, 2012.

----, A History of Modern Indonesia, ca. 1300 to the Present, Bloomington: Indiana University Press, 1981.

Roberson, Thomas, "My Jakarta: Noor Huda Ismail, Founder Institute for International Peace Building", Jakarta Globe, 31 Mar 2012, http:// www.thejakartaglobe.com/archive/my-jakarta-noor-huda-ismailfounder-institute-for-international-peace-building/508195/.

Roberts, George, "Incompetent Terrorists Test Indonesia's Luck", $A B C$ News, 14 Sep 2012, http://www.abc.net.au/news/2012-09-14/ incompetent-terrorists-test-indonesias-luck/4262508.

Rusli, Marah, Sitti Nurbaya: A Love Unrealized, English edition, Jakarta: Lontar Foundation, 2009.

Shofia, Naila and Piero Stanig, "Seven Out of Every Ten Muslims in 
Adam James Fenton

Indonesia Want Shariah - Really?”, Jakarta Globe, 10 May 2013, http://www.thejakartaglobe.com/opinion/seven-out-of-every-tenmuslims-in-indonesia-want-shariah-really/.

Sihalolo, Markus Junianto and Farouk Arnaz, "Bloody Densus 88 Raids Reveal Disturbing Detail”, Jakarta Globe, 11 May 2013, http:// www.thejakartaglobe.com/news/densus-88-searching-for-missingterrorist-funds/.

Sukma, Rizal, Jamhari Ma'ruf, and Kamarulnizam Abdullah, "The Attitude of Indonesian Muslims Towards Terrorism: An Important Factor in Counter-terrorism?", Journal of Human Security, vol. 7, no. 1, 2011, pp. 21-36 [doi: 10.3316/JHS0701021].

Templin, J., "Keeping Radical Islamists from Recruiting on Indonesia's Campuses", Time, 2013, http://www.time.com/time/video/ player/0,32068,1118418176001_2089992,00.html.

“The Financial Action Task Force Public Statement", The Financial Action Task Force, 21 Jun 2013, http://www.fatf-gafi.org/countries/d-i/ indonesia/documents/public-statement-june-2013.html.

Ungerer, Carl, Jihadists in Jail: Radicalisation and the Indonesian Prison Experience, Annual Report, Canberra: ASPI-RSIS, 2011, https:// www.aspi.org.au/publications/special-report-issue-40-jihadists-injail-radicalisation-and-the-indonesian-prison-experience/SR40_ jihadists_in_jail.pdf. 